\title{
Bradykinin receptors in GtoPdb v.2021.3
}

Joseph Coulson ${ }^{1}$, Réjean Couture ${ }^{2}$, Alexander Faussner ${ }^{3}$, Fernand Gobeil Jr${ }^{4}$, Fredrik LeebLundberg $^{5}$, Francois Marceau ${ }^{6}$, Werner Muller-Esterl ${ }^{7}$, Doug Pettibone ${ }^{8}$ and Bruce Zuraw $^{9}$

1. University of Edinburgh, UK

2. Université de Montréal, Canada

3. Ludwig-Maximilians-Universität, Germany

4. Université de Sherbrooke, Canada

5. Lunds Universitet, Sweden

6. Université Laval, Canada

7. Johann Wolfgang Goethe-University, Germany

8. Merck Research Laboratories, USA

9. University of California San Diego, USA

\begin{abstract}
Bradykinin (or kinin) receptors (nomenclature as agreed by the NC-IUPHAR subcommittee on Bradykinin (kinin) Receptors [91]) are activated by the endogenous peptides bradykinin (BK), [des-Arg ${ }^{9}$ ]bradykinin, Lys-BK (kallidin), [des-Arg $\left.{ }^{10}\right]$ kallidin, [Phospho-Ser ${ }^{6}$-Bradykinin, T-kinin (IleSer-BK), $\left[\mathrm{Hyp}^{3}\right]$ bradykinin and Lys-[Hyp $\left.{ }^{3}\right]$-bradykinin. Variation in pharmacology and activity of $\mathrm{B}_{1}$ and $B_{2}$ receptor antagonists at species orthologs has been documented. icatibant (Hoe140, Firazir) is approved in North America and Europe for the treatment of acute attacks of hereditary angioedema.
\end{abstract}

\section{Contents}

This is a citation summary for Bradykinin receptors in the Guide to Pharmacology database (GtoPdb). It exists purely as an adjunct to the database to facilitate the recognition of citations to and from the database by citation analyzers. Readers will almost certainly want to visit the relevant sections of the database which are given here under database links.

GtoPdb is an expert-driven guide to pharmacological targets and the substances that act on them. GtoPdb is a reference work which is most usefully represented as an on-line database. As in any publication this work should be appropriately cited, and the papers it cites should also be recognized. This document provides a citation for the relevant parts of the database, and also provides a reference list for the research cited by those parts. For further details see [18].

Please note that the database version for the citations given in GtoPdb are to the most recent preceding version in which the family or its subfamilies and targets were substantially changed. The links below are to the current version. If you need to consult the cited version, rather than the most recent version, please contact the GtoPdb curators.

\section{Database links}

Bradykinin receptors

https://www.guidetopharmacology.org/GRAC/FamilyDisplayForward?familyId=10

Introduction to Bradykinin receptors

https://www.guidetopharmacology.org/GRAC/FamilyIntroductionForward?familyId=10

Receptors

$\mathrm{B}_{1}$ receptor

https://www.guidetopharmacology.org/GRAC/ObjectDisplayForward?objectId=41

$\mathrm{B}_{2}$ receptor

https://www.guidetopharmacology.org/GRAC/ObjectDisplayForward?objectId $=42$

\section{References}


1. Alfie ME, Alim S, Mehta D, Shesely EG and Carretero OA. (1999) An enhanced effect of arginine vasopressin in bradykinin B2 receptor null mutant mice. Hypertension 33: 1436-40 [PMID:10373229]

2. Alfie ME, Sigmon DH, Pomposiello SI and Carretero OA. (1997) Effect of high salt intake in mutant mice lacking bradykinin-B2 receptors. Hypertension 29: 483-7 [PMID:9039146]

3. Amblard M, Bedos P, Olivier C, Daffix I, Luccarini JM, Dodey P, Pruneau D, Paquet JL and Martinez J. (2000) Synthesis and biological evaluation of bradykinin $B(1) / B(2)$ and selective $B(1)$ receptor antagonists. J Med Chem 43: 2382-6 [PMID:10882364]

4. Amblard M, Daffix I, Bedos P, Bergé G, Pruneau D, Paquet JL, Luccarini JM, Bélichard P, Dodey $\mathrm{P}$ and Martinez J. (1999) Design and synthesis of potent bradykinin agonists containing a benzothiazepine moiety. J Med Chem 42: 4185-92 [PMID:10514288]

5. Aramori I, Zenkoh J, Morikawa N, Asano M, Hatori C, Sawai H, Kayakiri H, Satoh S, Inoue T and Abe Y et al.. (1997) Nonpeptide mimic of bradykinin with long-acting properties at the bradykinin B2 receptor. Mol Pharmacol 52: 16-20 [PMID:9224807]

6. Aramori I, Zenkoh J, Morikawa N, O'Donnell N, Asano M, Nakamura K, Iwami M, Kojo H and Notsu Y. (1997) Novel subtype-selective nonpeptide bradykinin receptor antagonists FR167344 and FR173657. Mol Pharmacol 51: 171-6 [PMID:9203620]

7. Araújo RC, Mori MA, Merino VF, Bascands JL, Schanstra JP, Zollner RL, Villela CA, Nakaie CR, Paiva AC and Pesquero JL et al.. (2006) Role of the kinin B1 receptor in insulin homeostasis and pancreatic islet function. Biol Chem 387: 431-6 [PMID:16606341]

8. Audet R, Rioux F, Drapeau G and Marceau F. (1997) Cardiovascular effects of Sar-[D-Phe8]desArg9-bradykinin, a metabolically protected agonist of B1 receptor for kinins, in the anesthetized rabbit pretreated with a sublethal dose of bacterial lipopolysaccharide. J Pharmacol Exp Ther 280: 6-15 [PMID:8996175]

9. Austin CE, Faussner A, Robinson HE, Chakravarty S, Kyle DJ, Bathon JM and Proud D. (1997) Stable expression of the human kinin B1 receptor in Chinese hamster ovary cells. Characterization of ligand binding and effector pathways. J Biol Chem 272: 11420-5 [PMID:9111052]

10. Bachvarov DR, Landry M, Pelletier I, Chevrette M, Betard C, Houde I, Bergeron J, Lebel M and Marceau F. (1998) Characterization of two polymorphic sites in the human kinin B1 receptor gene: altered frequency of an allele in patients with a history of end-stage renal failure. J Am Soc Nephrol 9: 598-604 [PMID:9555662]

11. Bascands JL, Pecher C, Rouaud S, Emond C, Tack JL, Bastie MJ, Burch R, Regoli D and Girolami JP. (1993) Evidence for existence of two distinct bradykinin receptors on rat mesangial cells. Am J Physiol 264: F548-56 [PMID:8384416]

12. Bastian S, Loillier B, Paquet JL and Pruneau D. (1997) Stable expression of human kinin B1 receptor in 293 cells: pharmacological and functional characterization. Br J Pharmacol 122: 393-9 [PMID:9313952]

13. Bertram CM, Baltic S, Misso NL, Bhoola KD, Foster PS, Thompson PJ and Fogel-Petrovic M. (2007) Expression of kinin B1 and B2 receptors in immature, monocyte-derived dendritic cells and bradykinin-mediated increase in intracellular $\mathrm{Ca} 2+$ and cell migration. J Leukoc Biol 81: 1445-54 [PMID:17327486]

14. Bhat M, Pouliot M, Couture R and Vaucher E. (2014) The kallikrein-kinin system in diabetic retinopathy. Prog Drug Res 69: 111-43 [PMID:25130041]

15. Bhoola R, Ramsaroop R, Naidoo S, Müller-Esterl W and Bhoola KD. (1997) Kinin receptor status in normal and inflammed gastric mucosa. Immunopharmacology 36: 161-5 [PMID:9228541]

16. Borkowski JA, Ransom RW, Seabrook GR, Trumbauer M, Chen H, Hill RG, Strader CD and Hess JF. (1995) Targeted disruption of a B2 bradykinin receptor gene in mice eliminates bradykinin action in smooth muscle and neurons. J Biol Chem 270: 13706-10 [PMID:7775424]

17. Brull D, Dhamrait S, Myerson S, Erdmann J, Woods D, World M, Pennell D, Humphries S, Regitz-Zagrosek V and Montgomery H. (2001) Bradykinin B2BKR receptor polymorphism and left-ventricular growth response. Lancet 358: 1155-6 [PMID:11597672]

18. Buneman P, Christie G, Davies JA, Dimitrellou R, Harding SD, Pawson AJ, Sharman JL and Wu Y. (2020) Why data citation isn't working, and what to do about it Database 2020 [PMID:32367113]

19. Burch RM and Axelrod J. (1987) Dissociation of bradykinin-induced prostaglandin formation from phosphatidylinositol turnover in Swiss 3T3 fibroblasts: evidence for G protein regulation of phospholipase A2. Proc Natl Acad Sci USA 84: 6374-8 [PMID:2888113]

20. Burgess GM, Perkins MN, Rang HP, Campbell EA, Brown MC, McIntyre P, Urban L, Dziadulewicz EK, Ritchie TJ and Hallett A et al.. (2000) Bradyzide, a potent non-peptide B(2) bradykinin receptor antagonist with long-lasting oral activity in animal models of inflammatory hyperalgesia. BrJ Pharmacol 129: 77-86 [PMID:10694205]

21. Busse R and Fleming I. (1995) Regulation and functional consequences of endothelial nitric oxide formation. Ann Med 27: 331-340 [PMID:7546623]

22. Byron KL, Babnigg G and Villereal ML. (1992) Bradykinin-induced Ca2+ entry, release, and 
refilling of intracellular $\mathrm{Ca} 2+$ stores. Relationships revealed by image analysis of individual human fibroblasts. J Biol Chem 267: 108-18 [PMID:1730576]

23. Campos MM, Ongali B, De Souza Buck H, Schanstra JP, Girolami JP, Chabot JG and Couture R. (2005) Expression and distribution of kinin B1 receptor in the rat brain and alterations induced by diabetes in the model of streptozotocin. Synapse 57: 29-37 [PMID:15858836]

24. Campos MM, Ongali B, Thibault G, Neugebauer W and Couture R. (2005) Autoradiographic distribution and alterations of kinin $\mathrm{B}(2)$ receptors in the brain and spinal cord of streptozotocindiabetic rats. Synapse 58: 184-92 [PMID:16138314]

25. Cayla C, Todiras M, Iliescu R, Saul VV, Gross V, Pilz B, Chai G, Merino VF, Pesquero JB and Baltatu OC et al.. (2007) Mice deficient for both kinin receptors are normotensive and protected from endotoxin-induced hypotension. FASEB J 21: 1689-98 [PMID:17289925]

26. Cernit V, Sénécal J, Othman R and Couture R. (2020) Reciprocal Regulatory Interaction between TRPV1 and Kinin B1 Receptor in a Rat Neuropathic Pain Model. Int J Mol Sci 21 [PMID:32012798]

27. Cervenka L, Harrison-Bernard LM, Dipp S, Primrose G, Imig JD and El-Dahr SS. (1999) Early onset salt-sensitive hypertension in bradykinin $\mathrm{B}(2)$ receptor null mice. Hypertension 34: 176-80 [PMID:10454437]

28. Chai KX, Ni A, Wang D, Ward DC, Chao J and Chao L. (1996) Genomic DNA sequence, expression, and chromosomal localization of the human B1 bradykinin receptor gene BDKRB1. Genomics 31: 51-7 [PMID:8808279]

29. Cheuk BL, Ko WH and Wong PY. (2002) COX-dependent and -independent pathways in bradykinin-induced anion secretion in rat epididymis. J Cell Physiol 191: 217-226 [PMID:12064465]

30. Christopher J, Velarde V and Jaffa AA. (2001) Induction of B(1)-kinin receptors in vascular smooth muscle cells: cellular mechanisms of map kinase activation. Hypertension 38: 602-5 [PMID:11566939]

31. Chuang HH, Prescott ED, Kong H, Shields S, Jordt SE, Basbaum AI, Chao MV and Julius D. (2001) Bradykinin and nerve growth factor release the capsaicin receptor from PtdIns $(4,5) P 2-$ mediated inhibition. Nature 411: 957-62 [PMID:11418861]

32. Cloutier F, de Sousa Buck H, Ongali B and Couture R. (2002) Pharmacologic and autoradiographic evidence for an up-regulation of kinin $\mathrm{B}(2)$ receptors in the spinal cord of spontaneously hypertensive rats. Br J Pharmacol 135: 1641-54 [PMID:11934804]

33. Cockcroft JR, Chowienczyk PJ, Brett SE, Bender N and Ritter JM. (1994) Inhibition of bradykinin-induced vasodilation in human forearm vasculature by icatibant, a potent B2receptor antagonist. Br J Clin Pharmacol 38: 317-21 [PMID:7833220]

34. Conley RK, Wheeldon A, Webb JK, DiPardo RM, Homnick CF, Bock MG, Chen TB, Chang RS, Pettibone DJ and Boyce S. (2005) Inhibition of acute nociceptive responses in rat spinal cord by a bradykinin B1 receptor antagonist. Eur J Pharmacol 527: 44-51 [PMID:16310181]

35. Couture R, Mizrahi J, Regoli D and Devroede G. (1981) Peptides and the human colon: an in vitro pharmacological study. Can J Physiol Pharmacol 59: 957-64 [PMID:6170411]

36. D'Amico DC, Aya T, Human J, Fotsch C, Chen JJ, Biswas K, Riahi B, Norman MH, Willoughby CA and Hungate R et al.. (2007) Identification of a nonpeptidic and conformationally restricted bradykinin B1 receptor antagonist with anti-inflammatory activity. J Med Chem 50: 607-10 [PMID:17243660]

37. De Falco L, Fioravanti A, Galeazzi M and Tenti S. (2013) Bradykinin and its role in osteoarthritis. Reumatismo 65: 97-104 [PMID:23884024]

38. de Sousa Buck H, Ongali B, Thibault G, Lindsey CJ and Couture R. (2002) Autoradiographic detection of kinin receptors in the human medulla of control, hypertensive, and diabetic donors. Can J Physiol Pharmacol 80: 249-57 [PMID:12025957]

39. Dhamrait SS, Payne JR, Li P, Jones A, Toor IS, Cooper JA, Hawe E, Palmen JM, Wootton PT and Miller GJ et al.. (2003) Variation in bradykinin receptor genes increases the cardiovascular risk associated with hypertension. Eur Heart J 24: 1672-80 [PMID:14499231]

40. Dias JP and Couture R. (2012) Blockade of kinin B(1) receptor reverses plasma fatty acids composition changes and body and tissue fat gain in a rat model of insulin resistance. Diabetes Obes Metab 14: 244-53 [PMID:22023455]

41. Dias JP, Gariépy Hde B, Ongali B and Couture R. (2015) Brain kinin B1 receptor is upregulated by the oxidative stress and its activation leads to stereotypic nociceptive behavior in insulinresistant rats. Peptides 69: 118-26 [PMID:25959537]

42. Dias JP, Talbot S, Sénécal J, Carayon P and Couture R. (2010) Kinin B1 receptor enhances the oxidative stress in a rat model of insulin resistance: outcome in hypertension, allodynia and metabolic complications. PLoS ONE 5: e12622 [PMID:20830306]

43. Doctrow SR, Abelleira SM, Curry LA, Heller-Harrison R, Kozarich JW, Malfroy B, McCarroll LA, Morgan KG, Morrow AR and Musso GF et al.. (1994) The bradykinin analog RMP-7 increases intracellular free calcium levels in rat brain microvascular endothelial cells. J Pharmacol Exp Ther 271: 229-37 [PMID:7965719] 
44. Dray A, Bettaney J, Forster P and Perkins MN. (1988) Activation of a bradykinin receptor in peripheral nerve and spinal cord in the neonatal rat in vitro. Br J Pharmacol 95: 1008-10 [PMID:2905907]

45. Duka A, Duka I, Gao G, Shenouda S, Gavras I and Gavras H. (2006) Role of bradykinin B1 and B2 receptors in normal blood pressure regulation. Am J Physiol Endocrinol Metab 291: E268-74 [PMID:16507603]

46. Duka I, Shenouda S, Johns C, Kintsurashvili E, Gavras I and Gavras H. (2001) Role of the B(2) receptor of bradykinin in insulin sensitivity. Hypertension 38: 1355-60 [PMID:11751717]

47. Ehrenfeld P, Millan C, Matus CE, Figueroa JE, Burgos RA, Nualart F, Bhoola KD and Figueroa CD. (2006) Activation of kinin B1 receptors induces chemotaxis of human neutrophils. J Leukoc Biol 80: 117-24 [PMID:16670123]

48. El Akoum S, Haddad Y and Couture R. (2017) Impact of pioglitazone and bradykinin type 1 receptor antagonist on type 2 diabetes in high-fat diet-fed C57BL/6J mice. Obes Sci Pract 3: 352362 [PMID:29071111]

49. El-Dahr SS, Harrison-Bernard LM, Dipp S, Yosipiv IV and Meleg-Smith S. (2000) Bradykinin B2 null mice are prone to renal dysplasia: gene-environment interactions in kidney development. Physiol Genomics 3: 121-31 [PMID:11015607]

50. Eric J, Gabra BH and Sirois P. (2003) Implication of the bradykinin receptors in antigen-induced pulmonary inflammation in mice. Br J Pharmacol 138: 1589-97 [PMID:12721115]

51. Ewald DA, Pang IH, Sternweis PC and Miller RJ. (1989) Differential G protein-mediated coupling of neurotransmitter receptors to $\mathrm{Ca} 2+$ channels in rat dorsal root ganglion neurons in vitro. Neuron 2: 1185-93 [PMID:2560387]

52. Fallo F, Mulatero P, Vettor R, Scarda A, Della Mea P, Morello F, Veglio F and Williams TA. (2004) Bradykinin B2 receptor gene C-58T polymorphism and insulin resistance. A study on obese patients. Horm Metab Res 36: 243-6 [PMID:15114524]

53. Fasolato C, Pandiella A, Meldolesi J and Pozzan T. (1988) Generation of inositol phosphates, cytosolic Ca2+, and ionic fluxes in PC12 cells treated with bradykinin. J Biol Chem 263: 17350-9 [PMID:3141420]

54. Ferreira J, Beirith A, Mori MA, Araújo RC, Bader M, Pesquero JB and Calixto JB. (2005) Reduced nerve injury-induced neuropathic pain in kinin B1 receptor knock-out mice. J Neurosci 25: 240512 [PMID:15745967]

55. Figueroa CD, Marchant A, Novoa U, Förstermann U, Jarnagin K, Schölkens B and Müller-Esterl W. (2001) Differential Distribution of Bradykinin B(2) Receptors in the Rat and Human Cardiovascular System. Hypertension 37: 110-120 [PMID:11208765]

56. Fleming I, Fisslthaler B and Busse R. (1995) Calcium signaling in endothelial cells involves activation of tyrosine kinases and leads to activation of mitogen-activated protein kinases. Circ Res 76: 522-529 [PMID:7895328]

57. Fleming I, Fisslthaler B and Busse R. (1996) Interdependence of calcium signaling and protein tyrosine phosphorylation in human endothelial cells. J Biol Chem 271: 11009-15 [PMID:8631922]

58. Fox A, Kaur S, Li B, Panesar M, Saha U, Davis C, Dragoni I, Colley S, Ritchie T and Bevan S et al.. (2005) Antihyperalgesic activity of a novel nonpeptide bradykinin B1 receptor antagonist in transgenic mice expressing the human B1 receptor. Br J Pharmacol 144: 889-99 [PMID:15685199]

59. Fox A, Wotherspoon G, McNair K, Hudson L, Patel S, Gentry C and Winter J. (2003) Regulation and function of spinal and peripheral neuronal B1 bradykinin receptors in inflammatory mechanical hyperalgesia. Pain 104: 683-91 [PMID:12927641]

60. Gabra BH, Berthiaume N, Sirois P, Nantel F and Battistini B. (2006) The kinin system mediates hyperalgesia through the inducible bradykinin B1 receptor subtype: evidence in various experimental animal models of type 1 and type 2 diabetic neuropathy. Biol Chem 387: 127-43 [PMID:16497144]

61. Gabra BH, Merino VF, Bader M, Pesquero JB and Sirois P. (2005) Absence of diabetic hyperalgesia in bradykinin B1 receptor-knockout mice. Regul Pept 127: 245-8 [PMID:15680494]

62. Gabra BH and Sirois P. (2004) Pathways for the bradykinin B1 receptor-mediated diabetic hyperalgesia in mice. Inflamm Res 53: 653-7 [PMID:15654512]

63. Gera L, Fortin JP, Adam A, Stewart JM and Marceau F. (2006) Discovery of a dual-function peptide that combines aminopeptidase $\mathrm{N}$ inhibition and kinin B1 receptor antagonism. $J$ Pharmacol Exp Ther 317: 300-308 [PMID:16368899]

64. Gobeil F, Neugebauer W, Filteau C, Jukic D, Allogho SN, Pheng LH, Nguyen-Le XK, Blouin D and Regoli D. (1996) Structure-activity studies of B1 receptor-related peptides. Antagonists. Hypertension 28: 833-9 [PMID:8901831]

65. Gobeil F, Pheng LH, Badini I, Nguyen-Le XK, Pizard A, Rizzi A, Blouin D and Regoli D. (1996) Receptors for kinins in the human isolated umbilical vein. BrJ Pharmacol 118: 289-94 [PMID:8735629]

66. Gobeil Jr F, Sirois P and Regoli D. (2014) Preclinical pharmacology, metabolic stability, 
pharmacokinetics and toxicology of the peptidic kinin B1 receptor antagonist R-954. Peptides 52: 82-9 [PMID:24361511]

67. Gohla A, Offermanns S, Wilkie TM and Schultz G. (1999) Differential involvement of Galpha12 and Galpha13 in receptor-mediated stress fiber formation. J Biol Chem 274: 17901-7 [PMID:10364236]

68. Gougat J, Ferrari B, Sarran L, Planchenault C, Poncelet M, Maruani J, Alonso R, Cudennec A, Croci T and Guagnini F et al.. (2004) SSR240612 [(2R)-2-[((3R)-3-(1,3-benzodioxol-5-yl)-3-[[(6methoxy-2-naphthyl)sulfonyl]amino]propanoyl)amino]-3-(4-[[2R,6S)-2,6-

dimethylpiperidinyl]methyl]phenyl)-N-isopropyl-N-methylpropanamide hydrochloride], a new nonpeptide antagonist of the bradykinin B1 receptor: biochemical and pharmacological characterization. J Pharmacol Exp Ther 309: 661-9 [PMID:14747609]

69. Groves P, Kurz S, Just H and Drexler H. (1995) Role of endogenous bradykinin in human coronary vasomotor control. Circulation 92: 3424-30 [PMID:8521563]

70. Gutowski S, Smrcka A, Nowak L, Wu DG, Simon M and Sternweis PC. (1991) Antibodies to the alpha q subfamily of guanine nucleotide-binding regulatory protein alpha subunits attenuate activation of phosphatidylinositol 4,5-bisphosphate hydrolysis by hormones. J Biol Chem 266: 20519-20524 [PMID:1657928]

71. Hachana S, Bhat M, Sénécal J, Huppé-Gourgues F, Couture R and Vaucher E. (2018) Expression, distribution and function of kinin $\mathrm{B}_{1}$ receptor in the rat diabetic retina. BrJ Pharmacol 175: 968-983 [PMID:29285756]

72. Hachana S, Fontaine O, Sapieha P, Lesk M, Couture R and Vaucher E. (2020) The effects of antiVEGF and kinin $\mathrm{B}_{1}$ receptor blockade on retinal inflammation in laser-induced choroidal neovascularization. Br J Pharmacol 177: 1949-1966 [PMID:31883121]

73. Hachana S, Pouliot M, Couture R and Vaucher E. (2020) Diabetes-Induced Inflammation and Vascular Alterations in the Goto-Kakizaki Rat Retina. Curr Eye Res 45: 965-974 [PMID:31902231]

74. Haddad Y and Couture R. (2017) Localization and Interaction between Kinin B1 Receptor and NADPH Oxidase in the Vascular System of Diabetic Rats. Front Physiol 8: 861 [PMID:29163205]

75. Han ED, MacFarlane RC, Mulligan AN, Scafidi J and Davis 3rd AE. (2002) Increased vascular permeability in C1 inhibitor-deficient mice mediated by the bradykinin type 2 receptor. $J$ Clin Invest 109: 1057-63 [PMID:11956243]

76. Hayashi R, Yamashita N, Matsui S, Fujita T, Araya J, Sassa K, Arai N, Yoshida Y, Kashii T and Maruyama M et al.. (2000) Bradykinin stimulates IL-6 and IL-8 production by human lung fibroblasts through ERK- and p38 MAPK-dependent mechanisms. Eur Respir J 16: 452-8 [PMID:11028659]

77. Hess JF, Borkowski JA, MacNeil T, Stonesifer GY, Fraher J, Strader CD and Ransom RW. (1994) Differential pharmacology of cloned human and mouse B2 bradykinin receptors. Mol Pharmacol 45: 1-8 [PMID:8302267]

78. Hess JF, Derrick AW, MacNeil T and Borkowski JA. (1996) The agonist selectivity of a mouse B1 bradykinin receptor differs from human and rabbit B1 receptors. Immunopharmacology 33: 1-8 [PMID:8856107]

79. Higashida H, Streaty RA, Klee W and Nirenberg M. (1986) Bradykinin-activated transmembrane signals are coupled via No or Ni to production of inositol 1,4,5-trisphosphate, a second messenger in NG108-15 neuroblastoma-glioma hybrid cells. Proc Natl Acad Sci USA 83: 942-6 [PMID:3081891]

80. Horlick RA, Ohlmeyer MH, Stroke IL, Strohl B, Pan G, Schilling AE, Paradkar V, Quintero JG, You M and Riviello C et al.. (1999) Small molecule antagonists of the bradykinin B1 receptor. Immunopharmacology 43: 169-77 [PMID:10596850]

81. Houle S, Landry M, Audet R, Bouthillier J, Bachvarov DR and Marceau F. (2000) Effect of allelic polymorphism of the $\mathrm{B}(1)$ and $\mathrm{B}(2)$ receptor genes on the contractile responses of the human umbilical vein to kinins. J Pharmacol Exp Ther 294: 45-51 [PMID:10871294]

82. Imig JD, Zhao X, Orengo SR, Dipp S and El-Dahr SS. (2003) The Bradykinin B2 receptor is required for full expression of renal COX-2 and renin. Peptides 24: 1141-7 [PMID:14612184]

83. Jones C, Phillips E, Davis C, Arbuckle J, Yaqoob M, Burgess GM, Docherty RJ, Webb M, Bevan SJ and McIntyre P. (1999) Molecular characterisation of cloned bradykinin B1 receptors from rat and human. Eur J Pharmacol 374: 423-433 [PMID:10422787]

84. Kusser B, Braun A, Praun M, Illi S, von Mutius E and Roscher AA. (2001) Polymorphisms in the bradykinin B2 receptor gene and childhood asthma. Biol Chem 382: 885-9 [PMID:11517947]

85. Lacoste B, Tong XK, Lahjouji K, Couture R and Hamel E. (2013) Cognitive and cerebrovascular improvements following kinin B1 receptor blockade in Alzheimer's disease mice. $J$ Neuroinflammation 10: 57 [PMID:23642031]

86. Lagneux C, Bader M, Pesquero JB, Demenge P and Ribuot C. (2002) Detrimental implication of B1 receptors in myocardial ischemia: evidence from pharmacological blockade and gene knockout mice. Int Immunopharmacol 2: 815-22 [PMID:12095172]

87. LaMorte VJ, Harootunian AT, Spiegel AM, Tsien RY and Feramisco JR. (1993) Mediation of 
growth factor induced DNA synthesis and calcium mobilization by Gq and Gi2. J Cell Biol 121: 91-99 [PMID:8458876]

88. Lawson SR, Gabra BH, Guérin B, Neugebauer W, Nantel F, Battistini B and Sirois P. (2005) Enhanced dermal and retinal vascular permeability in streptozotocin-induced type 1 diabetes in Wistar rats: blockade with a selective bradykinin B1 receptor antagonist. Regul Pept 124: 221-4 [PMID:15544863]

89. Lawson SR, Gabra BH, Nantel F, Battistini B and Sirois P. (2005) Effects of a selective bradykinin B1 receptor antagonist on increased plasma extravasation in streptozotocin-induced diabetic rats: distinct vasculopathic profile of major key organs. Eur J Pharmacol 514: 69-78 [PMID:15878326]

90. Leeb T, Mathis SA and Leeb-Lundberg LM. (1997) The sixth transmembrane domains of the human B1 and B2 bradykinin receptors are structurally compatible and involved in discriminating between subtype-selective agonists. J Biol Chem 272: 311-317 [PMID:8995263]

91. Leeb-Lundberg LM, Marceau F, Müller-Esterl W, Pettibone DJ and Zuraw BL. (2005) International union of pharmacology. XLV. Classification of the kinin receptor family: from molecular mechanisms to pathophysiological consequences. Pharmacol Rev 57: 27-77 [PMID:15734727]

92. Leeb-Lundberg LM, Song XH and Mathis SA. (1994) Focal adhesion-associated proteins p125FAK and paxillin are substrates for bradykinin-stimulated tyrosine phosphorylation in Swiss 3T3 cells. J Biol Chem 269: 24328-34 [PMID:7929090]

93. Lesage A, Gibson C, Marceau F, Ambrosi HD, Saupe J, Katzer W, Loenders B, Charest-Morin X and Knolle J. (2020) In Vitro Pharmacological Profile of a New Small Molecule Bradykinin $B_{2}$ Receptor Antagonist. Front Pharmacol 11: 916 [PMID:32636746]

94. Liao JK and Homcy CJ. (1993) The G proteins of the G alpha i and G alpha q family couple the bradykinin receptor to the release of endothelium-derived relaxing factor. J Clin Invest 92: 2168-2172 [PMID:8227332]

95. Lin JC, Talbot S, Lahjouji K, Roy JP, Sénécal J, Couture R and Morin A. (2010) Mechanism of cigarette smoke-induced kinin B(1) receptor expression in rat airways. Peptides 31: 1940-5 [PMID:20637817]

96. Linder ME, Ewald DA, Miller RJ and Gilman AG. (1990) Purification and characterization of Go alpha and three types of Gi alpha after expression in Escherichia coli. J Biol Chem 265: 8243-51 [PMID:2159473]

97. Lopes P, Kar S, Chrétien L, Regoli D, Quirion R and Couture R. (1995) Quantitative autoradiographic localization of [125I-Tyr8]bradykinin receptor binding sites in the rat spinal cord: effects of neonatal capsaicin, noradrenergic deafferentation, dorsal rhizotomy and peripheral axotomy. Neuroscience 68: 867-81 [PMID:8577380]

98. Lopes P, Kar S, Tousignant C, Regoli D, Quirion R and Couture R. (1993) Autoradiographic localization of [125I-Tyr8]-bradykinin receptor binding sites in the guinea pig spinal cord. Synapse 15: 48-57 [PMID:8310425]

99. MacNeil T, Feighner S, Hreniuk DL, Hess JF and Van der Ploeg LH. (1997) Partial agonists and full antagonists at the human and murine bradykinin B1 receptors. Can J Physiol Pharmacol 75: 735-740 [PMID:9276157]

100. Maltais I, Bachvarova M, Maheux P, Perron P, Marceau F and Bachvarov D. (2002) Bradykinin $\mathrm{B} 2$ receptor gene polymorphism is associated with altered urinary albumin/creatinine values in diabetic patients. Can J Physiol Pharmacol 80: 323-327 [PMID:12025967]

101. Marceau F, Hess JF and Bachvarov DR. (1998) The B1 receptors for kinins. Pharmacol Rev 50: 357-86 [PMID:9755287]

102. Marceau F, Levesque L, Drapeau G, Rioux F, Salvino JM, Wolfe HR, Seoane PR and Sawutz DG. (1994) Effects of peptide and nonpeptide antagonists of bradykinin B2 receptors on the venoconstrictor action of bradykinin. J Pharmacol Exp Ther 269: 1136-43 [PMID:8014858]

103. McEachern AE, Shelton ER, Bhakta S, Obernolte R, Bach C, Zuppan P, Fujisaki J, Aldrich RW and Jarnagin K. (1991) Expression cloning of a rat B2 bradykinin receptor. Proc Natl Acad Sci USA 88: 7724-8 [PMID:1715575]

104. Menke JG, Borkowski JA, Bierilo KK, MacNeil T, Derrick AW, Schneck KA, Ransom RW, Strader CD, Linemeyer DL and Hess JF. (1994) Expression cloning of a human B1 bradykinin receptor. $J$ Biol Chem 269: 21583-21586 [PMID:8063797]

105. Minville V, Mouledous L, Jaafar A, Couture R, Brouchet A, Frances B, Tack I and Girolami JP. (2019) Tibial post fracture pain is reduced in kinin receptors deficient mice and blunted by kinin receptor antagonists. J Transl Med 17: 346 [PMID:31640792]

106. Moniwa N, Agata J, Hagiwara M, Ura N and Shimamoto K. (2006) The role of bradykinin B1 receptor on cardiac remodeling in stroke-prone spontaneously hypertensive rats (SHR-SP). Biol Chem 387: 203-9 [PMID:16497153]

107. Morissette G, Sabourin T, Adam A and Marceau F. (2006) Inhibition of human and rabbit arterial smooth muscle cell migration mediated by the kinin B1 receptor: role of receptor density and released mediators. Can J Physiol Pharmacol 84: 1107-19 [PMID:17218975] 
108. Mulatero P, Williams TA, Milan A, Paglieri C, Rabbia F, Fallo F and Veglio F. (2002) Blood pressure in patients with primary aldosteronism is influenced by bradykinin $\mathrm{B}(2)$ receptor and alpha-adducin gene polymorphisms. J Clin Endocrinol Metab 87: 3337-43 [PMID:12107246]

109. Ni A, Chai KX, Chao L and Chao J. (1998) Molecular cloning and expression of rat bradykinin B1 receptor. Biochim Biophys Acta 1442: 177-85 [PMID:9804950]

110. Nicoletti NF, Sénécal J, da Silva VD, Roxo MR, Ferreira NP, de Morais RLT, Pesquero JB, Campos MM, Couture R and Morrone FB. (2017) Primary Role for Kinin $B_{1}$ and $B_{2}$ Receptors in Glioma Proliferation. Mol Neurobiol 54: 7869-7882 [PMID:27848207]

111. Ongali B, Buck Hde S, Cloutier F, Legault F, Regoli D, Lambert C, Thibault G and Couture R. (2003) Chronic effects of angiotensin-converting enzyme inhibition on kinin receptor binding sites in the rat spinal cord. Am J Physiol Heart Circ Physiol 284: H1949-58 [PMID:12586640]

112. Ongali B, Campos MM, Bregola G, Rodi D, Regoli D, Thibault G, Simonato M and Couture R. (2003) Autoradiographic analysis of rat brain kinin B1 and B2 receptors: normal distribution and alterations induced by epilepsy. J Comp Neurol 461: 506-519 [PMID:12746865]

113. Ongali B, Hellal F, Rodi D, Plotkine M, Marchand-Verrecchia C, Pruneau D and Couture R. (2006) Autoradiographic analysis of mouse brain kinin B1 and B2 receptors after closed head trauma and ability of Anatibant mesylate to cross the blood-brain barrier. J Neurotrauma 23: 696-707 [PMID:16689671]

114. Othman R, Berbari S, Vaucher E and Couture R. (2020) Differential Expression of Kinin Receptors in Human Wet and Dry Age-Related Macular Degeneration Retinae. Pharmaceuticals (Basel) 13 [PMID:32599742]

115. Othman R, Vaucher E and Couture R. (2019) Bradykinin Type 1 Receptor - Inducible Nitric Oxide Synthase: A New Axis Implicated in Diabetic Retinopathy. Front Pharmacol 10: 300 [PMID:30983997]

116. Pan ZK, Zuraw BL, Lung CC, Prossnitz ER, Browning DD and Ye RD. (1996) Bradykinin stimulates NF-kappaB activation and interleukin 1beta gene expression in cultured human fibroblasts. J Clin Invest 98: 2042-9 [PMID:8903323]

117. Perkins MN and Kelly D. (1993) Induction of bradykinin B1 receptors in vivo in a model of ultraviolet irradiation-induced thermal hyperalgesia in the rat. BrJ Pharmacol 110: 1441-4 [PMID:8306084]

118. Perosa SR, Argañaraz GA, Goto EM, Costa LG, Konno AC, Varella PP, Santiago JF, Pesquero JB, Canzian M and Amado D et al.. (2007) Kinin B1 and B2 receptors are overexpressed in the hippocampus of humans with temporal lobe epilepsy. Hippocampus 17: 26-33 [PMID:17094085]

119. Pesquero JB, Araujo RC, Heppenstall PA, Stucky CL, Silva Jr JA, Walther T, Oliveira SM, Pesquero JL, Paiva AC and Calixto JB et al.. (2000) Hypoalgesia and altered inflammatory responses in mice lacking kinin B1 receptors. Proc Natl Acad Sci USA 97: 8140-5 [PMID:10859349]

120. Pesquero JB, Pesquero JL, Oliveira SM, Roscher AA, Metzger R, Ganten D and Bader M. (1996) Molecular cloning and functional characterization of a mouse bradykinin B1 receptor gene. Biochem Biophys Res Commun 220: 219-25 [PMID:8602848]

121. Powell SJ, Slynn G, Thomas C, Hopkins B, Briggs I and Graham A. (1993) Human bradykinin B2 receptor: nucleotide sequence analysis and assignment to chromosome 14. Genomics 15: 435-8 [PMID:7916737]

122. Prat A, Biernacki K, Pouly S, Nalbantoglu J, Couture R and Antel JP. (2000) Kinin B1 receptor expression and function on human brain endothelial cells. J Neuropathol Exp Neurol 59: 896906 [PMID:11079780]

123. Prat A, Weinrib L, Becher B, Poirier J, Duquette P, Couture R and Antel JP. (1999) Bradykinin B1 receptor expression and function on T lymphocytes in active multiple sclerosis. Neurology 53: 2087-92 [PMID:10599786]

124. Pruneau D, Paquet JL, Luccarini JM, Defrêne E, Fouchet C, Franck RM, Loillier B, Robert C, Bélichard P and Duclos H et al.. (1999) Pharmacological profile of LF 16-0687, a new potent non-peptide bradykinin B2 receptor antagonist. Immunopharmacology 43: 187-94 [PMID:10596852]

125. Pyne NJ, Tolan D and Pyne S. (1997) Bradykinin stimulates cAMP synthesis via mitogenactivated protein kinase-dependent regulation of cytosolic phospholipase A2 and prostaglandin E2 release in airway smooth muscle. Biochem J 328 ( Pt 2): 689-94 [PMID:9371732]

126. Regoli D, Nsa Allogho S, Rizzi A and Gobeil FJ. (1998) Bradykinin receptors and their antagonists. Eur J Pharmacol 348: 1-10 [PMID:9650825]

127. Ricupero DA, Romero JR, Rishikof DC and Goldstein RH. (2000) Des-Arg(10)-kallidin engagement of the B1 receptor stimulates type I collagen synthesis via stabilization of connective tissue growth factor mRNA. J Biol Chem 275: 12475-80 [PMID:10777533]

128. Ritchie TJ, Dziadulewicz EK, Culshaw AJ, Müller W, Burgess GM, Bloomfield GC, Drake GS, Dunstan AR, Beattie D and Hughes GA et al.. (2004) Potent and orally bioavailable non-peptide antagonists at the human bradykinin $\mathrm{B}(1)$ receptor based on a 2-alkylamino-5sulfamoylbenzamide core. J Med Chem 47: 4642-4 [PMID:15341478] 
129. Rizzi A, Gobeil F, Calò G, Inamura N and Regoli D. (1997) FR 173657: a new, potent, nonpeptide kinin B2 receptor antagonist. An in vitro study. Hypertension 29: 951-6 [PMID:9095082]

130. Rodriguez JA, De la Cerda P, Collyer E, Decap V, Vio CP and Velarde V. (2006) Cyclooxygenase2 induction by bradykinin in aortic vascular smooth muscle cells. Am J Physiol Heart Circ Physiol 290: H30-6 [PMID:16143655]

131. Ross D and Joyner WL. (1997) Resting distribution and stimulated translocation of protein kinase C isoforms alpha, epsilon and zeta in response to bradykinin and TNF in human endothelial cells. Endothelium 5: 321-32 [PMID:9588823]

132. Salvino JM, Seoane PR, Douty BD, Awad MM, Dolle RE, Houck WT, Faunce DM and Sawutz DG. (1993) Design of potent non-peptide competitive antagonists of the human bradykinin B2 receptor. J Med Chem 36: 2583-4 [PMID:8394936]

133. Samadfam R, Teixeira C, Bkaily G, Sirois P, de Brum-Fernandes A and D'Orleans-Juste P. (2000) Contribution of $\mathrm{B}(2)$ receptors for bradykinin in arthus reaction-induced plasma extravasation in wild-type or B(2) transgenic knockout mice. Br J Pharmacol 129: 1732-8 [PMID:10780980]

134. Savard M, Côté J, Tremblay L, Neugebauer W, Regoli D, Gariépy S, Hébert N and Gobeil Jr F. (2016) Safety and pharmacokinetics of a kinin B1 receptor peptide agonist produced with different counter-ions. Biol Chem 397: 365-72 [PMID:26565554]

135. Savard M, Labonté J, Dubuc C, Neugebauer W, D'Orléans-Juste P and Gobeil Jr F. (2013) Further pharmacological evaluation of a novel synthetic peptide bradykinin B2 receptor agonist. Biol Chem 394: 353-60 [PMID:23362191]

136. Sawada Y, Kayakiri H, Abe Y, Mizutani T, Inamura N, Asano M, Hatori C, Aramori I, Oku T and Tanaka H. (2004) Discovery of the first non-peptide full agonists for the human bradykinin $\mathrm{B}(2)$ receptor incorporating 4-(2-picolyloxy)quinoline and 1-(2-picolyl)benzimidazole frameworks. $J$ Med Chem 47: 2853-63 [PMID:15139763]

137. Sawutz DG, Salvino JM, Dolle RE, Casiano F, Ward SJ, Houck WT, Faunce DM, Douty BD, Baizman E and Awad MM et al.. (1994) The nonpeptide WIN 64338 is a bradykinin B2 receptor antagonist. Proc Natl Acad Sci USA 91: 4693-7 [PMID:8197121]

138. Schanstra JP, Duchene J, Praddaude F, Bruneval P, Tack I, Chevalier J, Girolami JP and Bascands JL. (2003) Decreased renal NO excretion and reduced glomerular tuft area in mice lacking the bradykinin B2 receptor. Am J Physiol Heart Circ Physiol 284: H1904-8 [PMID:12560214]

139. Schanstra JP, Neau E, Drogoz P, Arevalo Gomez MA, Lopez Novoa JM, Calise D, Pecher C, Bader M, Girolami JP and Bascands JL. (2002) In vivo bradykinin B2 receptor activation reduces renal fibrosis. J Clin Invest 110: 371-9 [PMID:12163456]

140. Sevcik MA, Ghilardi JR, Halvorson KG, Lindsay TH, Kubota K and Mantyh PW. (2005) Analgesic efficacy of bradykinin B1 antagonists in a murine bone cancer pain model. J Pain 6: 771-5 [PMID:16275602]

141. Souza DG, Lomez ES, Pinho V, Pesquero JB, Bader M, Pesquero JL and Teixeira MM. (2004) Role of bradykinin B2 and B1 receptors in the local, remote, and systemic inflammatory responses that follow intestinal ischemia and reperfusion injury. J Immunol 172: 2542-8 [PMID:14764727]

142. Steranka LR, Manning DC, DeHaas CJ, Ferkany JW, Borosky SA, Connor JR, Vavrek RJ, Stewart JM and Snyder SH. (1988) Bradykinin as a pain mediator: receptors are localized to sensory neurons, and antagonists have analgesic actions. Proc Natl Acad Sci USA 85: 3245-9 [PMID:2896357]

143. Stewart JM, Gera L, Hanson W, Zuzak JS, Burkard M, McCullough R and Whalley ET. (1996) A new generation of bradykinin antagonists. Immunopharmacology 33: 51-60 [PMID:8856115]

144. Su DS, Markowitz MK, DiPardo RM, Murphy KL, Harrell CM, O'Malley SS, Ransom RW, Chang RS, Ha S and Hess FJ et al.. (2003) Discovery of a potent, non-peptide bradykinin B1 receptor antagonist. J Am Chem Soc 125: 7516-7 [PMID:12812482]

145. Sugiura T, Tominaga M, Katsuya H and Mizumura K. (2002) Bradykinin lowers the threshold temperature for heat activation of vanilloid receptor 1. J Neurophysiol 88: 544-8 [PMID:12091579]

146. Talbot S, Dias JP, El Midaoui A and Couture R. (2016) Beneficial effects of kinin B1 receptor antagonism on plasma fatty acid alterations and obesity in Zucker diabetic fatty rats. Can J Physiol Pharmacol 94: 752-7 [PMID:27172260]

147. Talbot S, Lin JC, Lahjouji K, Roy JP, Sénécal J, Morin A and Couture R. (2011) Cigarette smokeinduced kinin B1 receptor promotes NADPH oxidase activity in cultured human alveolar epithelial cells. Peptides 32: 1447-56 [PMID:21600945]

148. Taub JS, Guo R, Leeb-Lundberg LM, Madden JF and Daaka Y. (2003) Bradykinin receptor subtype 1 expression and function in prostate cancer. Cancer Res 63: 2037-41 [PMID:12727816]

149. Tidjane N, Gaboury L and Couture R. (2016) Cellular localisation of the kinin B1R in the pancreas of streptozotocin-treated rat and the anti-diabetic effect of the antagonist SSR240612. Biol Chem 397: 323-36 [PMID:26841446] 
150. Tidjane N, Hachem A, Zaid Y, Merhi Y, Gaboury L, Girolami JP and Couture R. (2015) A primary role for kinin B1 receptor in inflammation, organ damage, and lethal thrombosis in a rat model of septic shock in diabetes. Eur J Inflamm 13: 40-52 [PMID:26413099]

151. Tilly BC, van Paridon PA, Verlaan I, Wirtz KW, de Laat SW and Moolenaar WH. (1987) Inositol phosphate metabolism in bradykinin-stimulated human A431 carcinoma cells. Relationship to calcium signalling. Biochem J 244: 129-35 [PMID:3663107]

152. Tippmer S, Quitterer U, Kolm V, Faussner A, Roscher A, Mosthaf L, Müller-Esterl W and Häring H. (1994) Bradykinin induces translocation of the protein kinase $C$ isoforms alpha, epsilon, and zeta. Eur J Biochem 225: 297-304 [PMID:7925449]

153. Trabold F, Pons S, Hagege AA, Bloch-Faure M, Alhenc-Gelas F, Giudicelli JF, Richer-Giudicelli C and Meneton P. (2002) Cardiovascular phenotypes of kinin B2 receptor- and tissue kallikreindeficient mice. Hypertension 40: 90-5 [PMID:12105144]

154. Uknis AB, DeLa Cadena RA, Janardham R, Sartor RB, Whalley ET and Colman RW. (2001) Bradykinin receptor antagonists type 2 attenuate the inflammatory changes in peptidoglycaninduced acute arthritis in the Lewis rat. Inflamm Res 50: 149-55 [PMID:11339503]

155. Wang DZ, Chao L and Chao J. (1997) Hypotension in transgenic mice overexpressing human bradykinin B2 receptor. Hypertension 29: 488-93 [PMID:9039147]

156. Wilk-Blaszczak MA, Singer WD, Gutowski S, Sternweis PC and Belardetti F. (1994) The G protein G13 mediates inhibition of voltage-dependent calcium current by bradykinin. Neuron 13: 1215-24 [PMID:7946358]

157. Windischhofer W and Leis HJ. (1997) [3H]bradykinin receptor-binding, receptor-recycling, and receptor-internalization of the B2 bradykinin receptor in the murine osteoblast-like cell line MC3T3-E1. J Bone Miner Res 12: 1615-25 [PMID:9333122]

158. Wood MR, Kim JJ, Han W, Dorsey BD, Homnick CF, DiPardo RM, Kuduk SD, MacNeil T, Murphy KL and Lis EV et al.. (2003) Benzodiazepines as potent and selective bradykinin B1 antagonists. J Med Chem 46: 1803-6 [PMID:12723943]

159. Wotherspoon G and Winter J. (2000) Bradykinin B1 receptor is constitutively expressed in the rat sensory nervous system. Neurosci Lett 294: 175-8 [PMID:11072143]

160. Wu J, Akaike T, Hayashida K, Miyamoto Y, Nakagawa T, Miyakawa K, Müller-Esterl W and Maeda H. (2002) Identification of bradykinin receptors in clinical cancer specimens and murine tumor tissues. Int J Cancer 98: 29-35 [PMID:11857381]

161. Yanaga F, Hirata M and Koga T. (1991) Evidence for coupling of bradykinin receptors to a guanine-nucleotide binding protein to stimulate arachidonate liberation in the osteoblast-like cell line, MC3T3-E1. Biochim Biophys Acta 1094: 139-46 [PMID:1654114]

162. Yang XP, Liu YH, Scicli GM, Webb CR and Carretero OA. (1997) Role of kinins in the cardioprotective effect of preconditioning: study of myocardial ischemia/reperfusion injury in B2 kinin receptor knockout mice and kininogen-deficient rats. Hypertension 30: 735-40 [PMID:9323015]

163. Yano K, Higashida H, Hattori H and Nozawa Y. (1985) Bradykinin-induced transient accumulation of inositol trisphosphate in neuron-like cell line NG108-15 cells. FEBS Lett 181: 403-6 [PMID:2857660]

164. Zhang SP and Codd EE. (1998) Characterization of bradykinin receptors in human lung fibroblasts using the binding of 3[H][Des-Arg10,Leu9]kallidin and [3H]NPC17731. Life Sci 62: 2303-14 [PMID:9651119]

165. Zhang SP, Wang HY, Lovenberg TW and Codd EE. (2001) Functional studies of bradykinin receptors in Chinese hamster ovary cells stably expressing the human B2 bradykinin receptor. Int Immunopharmacol 1: 955-65 [PMID:11379050]

166. Zuccollo A, Navarro M, Frontera M, Cueva F, Carattino M and Catanzaro OL. (1999) The involvement of kallikrein-kinin system in diabetes type I (insulitis). Immunopharmacology 45: 69-74 [PMID:10614992]

167. Zwick E, Daub H, Aoki N, Yamaguchi-Aoki Y, Tinhofer I, Maly K and Ullrich A. (1997) Critical role of calcium- dependent epidermal growth factor receptor transactivation in PC12 cell membrane depolarization and bradykinin signaling. J Biol Chem 272: 24767-70 [PMID:9312072] 